\title{
Omani Renaissance in International Relations and Political Economy
}

\author{
M. Cuneyt Yenigun ${ }^{1}$ and Saranjam Baig ${ }^{2}$ \\ ${ }^{1}$ Director of International Relations and Security Studies Graduate Programs, Founder \\ Head of Political Science Department, College of Economics and Political Science, \\ Sultan Qaboos University, Oman \\ ${ }^{2}$ Assistant Professor, Political Science Department, College of Economics and \\ Political Science, Sultan Qaboos University, Oman
}

\section{ABSTRACT}

In the last century, though the Sultanate of Oman was seen as an undeveloped country in terms of economics, politics, international relations, and socio-cultural relations, actually, it had been one of the most developed countries in the Middle East previously. Perhaps, because of the existence of historical state experience in her DNAs, and His Majesty Sultan Qaboos' rational governance, Oman has developed and evolved visibly and started to compete with modern countries in the last fifty years. Today, Oman became the most democratic country among the Arabic Gulf countries, top-10 in the university graduation ratio in the world, top-8 in health development according to the WHO, and the safest country for the expatriates in the world. Oman had established a maritime empire in the 17th-19th centuries, but later it started to lose power by the British arrival to the region; then it started to follow isolationist policies in international relations because of new circumstances. After Sultan Qaboos came in power in 1970, first economic and transport, later socio-cultural and democratic developments brought Oman prominence in the Gulf. He pursued wise and balanced foreign affairs among its neighbors in the Gulf, Iran, and the West, and then started to be mediator and backchannel in the region reciprocally. This article shows how Oman succeeded a renaissance in society, politics, economics and international relations.

KEY WORDS: OMANI RENAISSANCE, OMANI CULTURE, OMAN'S POLITICAL ECONOMY, OMAN FOREIGN POLICY, MIDDLE EAST STUDIES.

\section{INTRODUCTION}

In the year 1970, the Oman Sultanate was a country having only a few primary schools, a single secondary school, and a few hospitals with only 3 kilometers of

\section{ARTICLE INFORMATION}

Received 30th Oct 2020 Accepted after revision 13th Dec 2020 Print ISSN: 0974-6455 Online ISSN: 2321-4007 CODEN: BBRCBA

Thomson Reuters ISI Web of Science Clarivate Analytics USA and Crossref Indexed Journal

\section{Clarivate
Analytics}

NAAS Journal Score 2020 (4.31)

A Society of Science and Nature Publication,

Bhopal India 2020. All rights reserved.

Online Contents Available at: http//www.bbrc.in/

Doi: http://dx.doi.org/10.21786/bbrc/13.15/15 asphalt roads. It was a country that was very isolated from the world under the 38 years' reign of Sultan Said bin Taimur, where even wearing sunglasses was forbidden. The Sultan had retreated to the Palace after an assassination attempt aimed at him. The doors of the city, which were surrounded by the walls and located on the seashore, were closed before it got dark. The Jebel-ul Akhdar War and the Dhofar uprising were taking place in the middle and the southern parts of the country for the second time. The economy of the country was totally closed to the outside world, and the natural resources of the country, petroleum, natural gas, and gold were remaining idle. Since there were no relations established with foreign countries, except Britain, the country was facing full isolation in its international relations. 
As the only son of the Sultan, Qaboos bin Said received the first part of his education in Salalah until the age of 16, and then completed his high school education at the Bury Saint Adams School in Britain. At the age of 20, he entered the Royal Military Academy at Sandhurst and completed his education there in 1962. Following his graduation, he was placed in the British military base in Germany, as a military officer with his Scottish Rifles (the Cameroonians). After these experiences, he studied the local governments in the UK, and then together with his close friend, Leslie Chauncy, he went on a world tour for 1.5 years and completed his education. It was the year 1966 when he came back to Oman after 10 years abroad. A new phase was starting in the life of Qaboos bin Said as he was kept in the Salalah Palace just after he arrived in the country. Qaboos went through Islamic education and took lessons of Oman's history during those years in the Palace.

On July 23, 1970, with the assistance of Britain, Qaboos made a bloodless coup d'état against his father. During the coup against him, Sultan Said shot one of the putschists and he shot himself in his foot by mistake. Sultan was captured by the British and sent to Bahrain for treatment. Later, he was put in confinement in a suite in the Dorchester Hotel, a hotel in London owned by Brunei, one of the most expensive hotels in the world at that time. He passed away there almost two years later.

:2. Creating A Nation: It is known that there are three ancient civilizations in the Arabian Peninsula: the civilization of Mecca and Medina, the Bahrain civilization and the civilization of Oman, which also covers today's United Arab Emirates. As distinct from the first two, Oman had established a powerful Maritime Empire between the 17th and 19th centuries, extending from Iran \& Pakistan to Mozambique. The people of Oman, who were living along with ten different civilizations those days until the 19th century, called the Golden Age of Oman brought multiculturism and tolerance to their socio-cultural life. From these days onwards, until today, Oman has achieved a multicultural characteristic, different from other people in the Peninsula, which resulted, with the passing of the years, in the development of tolerance in the country. In the first place, one could notice the civilized socio-cultural structure existing in the Omani Society. Arabs know each other very well than any other nations and each of the nations are given a nickname. The nickname of Omanis is "Madani" which means "civilized." Therefore, when Sultan Qaboos came to the power in 1970, the country did not have almost anything hard power but, as its biggest power resource, it has a "civilized" nation of 723.000 (World Bank, 2020) people (including foreigners), polite and honored, which once had established a maritime empire in recent history.

In contrast to other states of the Arab Peninsula, Oman is the only country that has experienced two civil wars. When Sultan Qaboos came to power in 1970, the country was still feeling the repercussions of the Jebel-Akhdar
War (1954; 1967-1967). Once Britain totally withdrew from the Gulf region (as did Oman as of 1978), the Soviet Union and China started to support the uprising in Dhofar, the most southern point of the country. Since the Sultan and Oman were considered as part of the capitalist block due to their close relations with Britain, the communist block was supporting the rebels with training, equipment, arms logistics, and paramilitary groups with the understanding that "my enemy's enemy is my friend".

Both Sultan Said and Sultan Qaboos were supported by the British in these wars. Rather than giving direct military and logistic support, with a very rational policy, Britain has chosen to bring soldiers from Jordan in the Jebel-Akhdar War and from Iran and Pakistan (especially from Baluchistan) in the Dhofar War. After the wars, these soldiers, who so desired, were given Omani citizenship on the condition that they relinquish their original passports. The people coming from the fallen Empire of Zanzibar were granted Omani citizenship. Later, in a new wave, those who came from India, Iran and Pakistan were also partially provided with citizenship. In 1971, the UAE seceded from Oman and established its own federation with the close assistance of Britain. In the remaining territory, the Sultan started to construct a new peaceful, multicultural and tolerant nation by following an equally distant policy (or close) to everybody.

As in all other Gulf countries, the state is the main job-provider in Oman as well. The quality and justice practiced by the state could be used as a means of equal distancing, which the state maintained for all tribes and origins. In Oman, it is possible to observe this equality in all public works and government posts established since 1970. In the Gulf region, tribes are the most important and powerful actors in socio-cultural life. The groups which had come to Oman at later stages, as above mentioned, also established their own tribes. If one looks at the state-nation profiles in the Gulf, it can be seen that the most ideal relationship between the state and the tribes is the one existing in Oman. This is one of the most important achievements of Sultan Qaboos.

Today, almost half of the population is made up of foreigners (2.2 million/4.6 million). Even though nonMuslims make up 15\% of the total population, they also pray for the health and success of the Sultan. The most important factor beyond this situation is the welfare established by the Sultan and the "security for all" principle applied in the country. In 2019, Expat Insider announced Oman as being the most secure country for foreigners (Expat Insider, 2019). Oman was ranked as the 32 nd country in terms of the general quality of life. Weather conditions affecting the whole country for 8 months over a year is the most significant factor in lowering the country's rating in this category. Upon his ascent to reign, the Sultan established a Consultative Council. He mingled freely among his people, sitting in a village square and listening to their problems. All these indicated, from the very beginning, that Oman would 
have such a state-people relationship that it would be very different from what was present in other countries in the region.

Except for the last period of his reign, during which he suffered a serious illness, Sultan Qaboos used to organize regular tours visiting all the provinces in the country together with a few clerks accompanying him. In these tours, the Sultan used to get the views and petitions of the local people and, accordingly, he was determining the new areas of interests and necessities, and, if necessary, he was giving "to-do lists" (Oman MOFA, 2020) for the regions to his ministers. Every Friday, people were gathering along the way leading to the Palace, and sometimes they were submitting their wishes and grievances to him and sometimes, he was receiving their greetings and distributing plenty of gifts and money to the people surrounding him.

3. Building The Country And The Economy From Scratch: In 1970, Oman was still stricken by poverty though the first oil reservoirs had been discovered in Oman back in 1962. Petroleum had for the first time been drilled out in Yiba in 1967 (and two years later in Nith and Faoud). Sultan Qaboos came to power in a war environment where there were no roads, electricity (and hence no A/C), water, etc. The Sultan, who had lived abroad for the last ten years, was aware of Europe's dependence on oil and he knew that he could develop and reconstruct his country only with the help of the money coming from oil (Petro-dollars). PDO (Petroleum Development Oman) had been established in 1967 during the reign of his father. The partners of the company and their shares were as follows: Shell: 85\%; Compagnie Francaise des Petroles: 10\% and Partex 5\%. The state of Oman did not have any share of the oil existing in the country. Just after two months following his ascendance to power, the new Sultan visited the company. He renewed all the agreements made with the drilling companies. He had $75 \mathrm{~km}$ of pipelines laid for the oil reservoirs that had been newly discovered.

In 1974, the Oman State participated in PDO with a share of 25\%. In 1979, the share of the state was increased to $60 \%$. Oman succeeded in having Shell, Compagnie Francaise des Petroles and Partex to accept company shares of 34\%, 4\%, and 2\% respectively. Today PDO still keeps the same partnership structure. The oil production, which was 281.000 barrels a day, increased to 972,000 barrels as of today (Hellenic, 2019). The total length of pipelines laid down for oil production is $35,600 \mathrm{~km}$ while this number is 4,230 for natural gas production. Today Oman is at the 21st place in the world in terms of the production of crude oil and at the 14th place in terms of its exportation. The country occupies 26th place in the world in terms of the production of natural gas and 20th place in terms of its exportation.

Sultan Qaboos' perspective on oil partnership was based on an analytical logic based on a "win-win" understanding. Although Oman had oil reservoirs, it did not have the technology to extract it, and it had to do business with one or more of the 7 sisters (Exxon, Shell, BP, Mobil, Texaco, Gulf, and Chevron) who would extract this oil. As a matter of fact, in his speech in 1995, he described the relations with the private sector in a very positive manner. Emphasizing the benefits of free enterprise and competition in his speech, he said that the private sector was the backbone of all modern economies and that Islam "recognized and respected private property and called individuals to work" (CIA Factbook, 2020). During the years of the country's foundation, the private sector was almost non-existent and lacked high industry and technology. The same was true for the state. Sultan Qaboos, whose aim was to establish a real country and state with the money that would come from oil, achieved this purpose through agreements that he made. Unlike the royal families of other countries, he did not happen to be an extravagant ruler. Especially the petro-dollars coming from PDO were used for the enhancing of the welfare of the whole country. Today, the country has 500,000 telephone lines, 5 television channels, 2.5 million internet users (an average of 3 internet connections to a house), 13 airports, and 65,000 km of modern asphalt roads.

Today, 99.1\% of Oman has access to electricity. It is possible to find electricity, water, and roads even in a hamlet with a population of 30 people, located in the most remote corner of the country. In 1970, there were two electric generators in Oman, one serving a small part of Muscat and the other serving the Sultan's palace in Salalah. Today, more than 20 billion kWh of electricity is produced in the country (US Energy Data Center, 2020) While a limited number of doctors were using candlelight in surgeries in 1970, today Oman ranks seventh in the world in electricity production. Unlike all Gulf countries, there is no single village or hamlet in Oman without electricity as of the year 2020. One should also bear in mind that, while there is a limited number of villages in Qatar, most of the country in the UAE consists of plains and sand. Therefore, road construction in these two countries is very easy and low cost. However, Oman has a very difficult topography with mountainous and deep canyons, and road construction costs are 9 times higher than those in the UAE are. Despite this fact, asphalt roads are paved in all settlements throughout its wide territory.

In short, years ago the country achieved the "interconnectivity", which is considered one of the most important achievements for a country. The country was able to catch up visibly to the 21 st century modernity under the reign of Sultan Qaboos. Therefore, unlike in other Arab countries, the Sultan was named "the father of the nation", which is the highest title of respect that could be given to a person in the Gulf region, and it was possible to hear this title even in Friday sermons.

No country in the modern world can compete internationally without first establishing a modern air transport system. Bait al-Falaj Airport, which was first built as a runway in the countryside for military purposes in 1929 in Oman was expanded in the 1960s. Being aware of the serious problems of this inadequate 
facility in 1970, Sultan Qaboos started the construction of Seeb Airport, which is today called Muscat International Airport. Opened in 1973, the new Airport hosted 87,000 passengers by the end of the first year (Oman Airports, 2020) The second-largest airport in the country was established in Salalah, which has become the main artery of the country's rapidly growing business and tourism industry. Today, Oman Airlines operates direct flights to 13 airports in the country, including the airports of Salalah, Khasab, Duqm, and other airports located near the major oil facilities.

Before 1970, in addition to other shortcomings in the country, the people of Oman were also feeling the absence of adequate communication infrastructure. Just one week after he came to power in 1970, Sultan Qaboos issued his first decree to correct this situation and ordered the foundation of the Oman Radio. First, broadcasting started from a small station in Bait el-Falaj near Muscat and the second station in Salalah the following year. Three other private radio stations were added in 2007. In 1974, the first state television station had started broadcasting from Muscat just like the radio stations. Today, five television stations, under state and private ownership, are broadcasting from Muscat. In 2020, 96 percent of the Oman households have television sets; there are 315,000 telephone lines and more than 5.6 million mobile phones connected to the network.

Despite invitations since its foundation, modern Oman has always refused to join OPEC. This preference freed Oman in its petro-politics to which it is highly dependent, freed it from quota restrictions, and kept its country development at a sustainable level by opening space for the execution of an individual foreign economic policy. This enabled it to carry out its exports even during the periods of constraints on oil production. In fact, as will be mentioned later, Oman avoids the membership of many international organizations. For example, it has a position against NATO's Gulf Partnership Initiative and Istanbul Cooperation Initiative (ICI), it opposes the transformation of the Gulf Cooperation Organization (GCC) into a Gulf Union (GU), and it is not a member of the Red Crescent. It could be claimed that the geopolitical position of Oman (it is located between Saudi Arabia and Iran) the influence of different cultures over the politics and the fact that Oman is a small state has been the main factor behind its staying outside all these organizations. However, it also cannot be denied that the choice of remaining outside $\mathrm{OPEC}$ has provided additional income to the country.

For almost 50 years, Sultan Qaboos has attempted to develop policies to encourage the development of economic activities outside the scope of the oil business. To that end, the Oman Investment and Export Promotion Center was established. Its purpose has been to create a basis for production and exportation. In this framework, steel, cement, ceramics, marbles, fiber optic, and electric cables, packaging materials, fertilizers, perfumes, and the fishery industry were selected as target sectors. The share of tourism among the promoted sectors was 8\%. Even though quite a large amount of money has been spent for this purpose up to now, the biggest problem faced by the Omani economy is the lack of diversification and dependence on oil income.

When the previous century is reviewed, there are mainly four sources of income for the people in Oman: Fishery, agriculture in a limited number of products, sea commerce/shipping, and frankincense. When the Sultan came to power, he introduced new laws, decrees, and incentives to support agriculture and the fishery sector. There were large-scale agricultural lands in Batinah and Dhofar, which had continuously been used for centuries. A wide variety of products are grown in large farms in areas surrounding Nizwa and Jebel-Akhdar.

Today Oman continues to produce certain agricultural products, such as bananas, coconuts, green lemons (lime), tomatoes, potatoes, onions, date palms, pomegranates, and roses, in large quantities. Similar to the tea terraces in the Black Sea Region, terraced rose gardens in JebelAkhdar, the second-highest mountain in the Arabian Peninsula, are natural areas worth viewing. In 2009, the government initiated the "Million Date Palm Project" in most of the country and started providing new subsidies. With oil prices rising as a result of the 2008 Global Economic Crisis and the 2011 Arab Spring, petrodollars flew to the country in such a great volume that had never been seen before. This money was spent to open new horizons in Oman, especially in agriculture. The government imported new modern machines and irrigation systems to increase farmers' productivity. Besides, funds were allocated, and arrangements were made for the protection and development of traditional conduits (Falaj system).

One of the most important services provided by Sultan Qaboos is the measures that he took to meet the water demand, which is the main problem of all countries in the region. The most important topographic advantage compared to other Gulf countries is the existence of the two highest mountains of the Arabian Peninsula in Oman. Because of the precipitation received there, rivers, though in limited numbers, are formed in this geography, and water resources became available. Since the soil does not absorb water, in the past the water used to flow into the sea. To prevent this situation, 43 reservoir dams with a total storage capacity of 93.5 million cubic meters (Oman Water Society, 2020), some of them under the ground and some on the surface have been built in the country over the past 50 years (DIAM, 2020). Surveys are still underway for the construction of dams in four different cities.

Also to the dams, the government has sought to create a source of drinking water by desalination, the world's most expensive water supply technique, to reduce dependence on scarce groundwater. All desalination plants are built by foreign investment companies and today they are still in operation. DIAM, the largest water producer, purchases the water produced by these facilities through the Oman Energy and Water Supply (OEWP) 
and manages the supply, storage, and distribution of the water to the Oman population. After these measures, no shortage of drinking water has been experienced in 0 man for the last 40 years. Ports are known as vessels or channels for the foreign trade of a country. This is true also for Oman, which has a strategic position over the Strait of Hormuz and is historically known as Sinbad's country. Ports have been of great importance for Oman with its rich maritime history. However, when the Sultan came to power, these ports were far from being modern and had a rather ineffectual situation.

The Omani Renaissance, which began in 1970, not only resurrected many old ports along 1,100 miles of coastline but also built new facilities and ports to maintain competitiveness in the modern global market. Port Sultan Qaboos is the lifeblood of the country's economy in the Mutrah region. It is believed that the government's decision to divert all commercial import and export operations to Sohar will also revive the historic role of this important port. It was possible to complete the construction of Sohar Port, which started in 1999, with an enormous cost of $\$ 26$ billion. The port handles more than one million tons of sea freight each week and about 3,500 ships per year (Sohar Port and Free Zone, 2020) Salalah, which is located at an equal distance between the Indian Peninsula and the Red Sea, also provides a strategic location to Oman as a global transfer point. In fact, there is a much more important project in Oman than these: building the largest port and "hub" of the Middle East.

The Duqm Port, which overlooks the Arabian Sea and the Indian Ocean beyond, located on the southeast coast of the Sultanate of Oman, has recently been completed as a port above world standards with its long dock walls and wide basin. The port was built by the Chinese Government using the build-operate-transfer model. Together with the $\$ 18$ billion that has been spent so far, the port is estimated to cost about $\$ 40$ billion with the completion of connecting routes and other details. China has recently begun opening the China-Pakistan Economic Corridor (CPEC) by land to expand into the Middle East. In addition, for the sea leg of this corridor, it is stated that Oman-Duqm link will be used. China's undertaking the construction of the port is often associated with this issue.

4. Education and Health: In the first years of Sultan Qaboos' rule, there were different political groups in the country. After strengthening the political stability, the Sultan made the political system more inclusive through legislative arrangements. He then turned his attention to raising the standard of living, and in that sense, he focused particularly on education and health. In fact, large-scale reforms in Omani society were developed "top-down" rather than bottom-up. Moreover, the first two "legs" of these reforms took place in the education and health sectors.

In 1970, there were only three primary schools in Oman with nine hundred students. The primary school
(Sayddiah school), which was opened in 1929, was open only to boys and was a state-funded institution. Later, two more schools were opened in Mutrah and Salalah. In addition, there were Qur'an courses in many neighborhoods. There were also some international schools in the capital, especially for the children of foreigners. In the first year of the Omani Renaissance, the government completed the construction of 16 schools where 7,000 students could study; and by 1972, this number had reached forty-five schools with 15,000 student enrollments (Nasser, 2019). During this period, many teachers were mostly brought from abroad. In the last 50 years, 471 private schools have been established in 0 man, 40 of which are international schools (Oman Ministry of Education, 2020). Immigrants from various countries including Britain, America, India, Australia, and Pakistan have established educational institutions that cater to the different communities living in Oman. From the very first years, Sultan Qaboos also supported foreign language education. The presence of women in the education sector is particularly striking.

In 2018, female students accounted for most of the graduate-level students (with 68 percent), while their graduation rates exceeded those of men (Oman Ministry of Higher Education, 2020). Currently, there are 54 universities (and their equivalent) in Oman, both public and private. Meanwhile, considering that its population is 4.6 million including foreigners, it should be noted that this ratio has surpassed many Western countries. Of these, 19 are private colleges and 7 are private universities. In the country, full scholarships are offered to 7,000 promising young people both at home and abroad. Sultan Qaboos University consists of nine faculties, including Arts and Social Sciences, Education, Economics and Political Science, Nursing, Law, Medicine and Health Sciences, Physical Sciences, Agriculture and Marine Sciences, and Engineering. The university, which has approximately 17,000 students and 1,000 academicians from 113 different countries, ranks 379th (QS Ranking 2020) in the world (Tuzlukova, Inguva, Sancheti, 2019).

In 1970, nobody would be expecting that a 29-year-old young man, about whom no one knew, would lead such a transformation as the Sultan of Oman. Nevertheless, Sultan Qaboos transformed the country substantially by fulfilling more than he promised, particularly in the fields of health and education. When Sultan Qaboos ascended to the throne, health services in Oman were virtually nonexistent. Very limited levels and numbers of health services were provided primarily by the British and then largely by the American missionaries. One of the biggest obstacles to healthcare in Oman at the time was the lack of electricity. After the establishment of a large Power Plant in Riyam Bay in 1961 and the discovery of oil in commercial quantities in 1964, a new twenty-bed hospital was opened in the capital, built by the national oil company Petroleum Development Oman (PDO), but it was not open to the public, serving only the company's employees and their families (26) Again, in the pre-1970 
period, the infant mortality rate was very high, and the average life expectancy was 49.6 years (UN, 2019)

Today, almost everything has changed in Oman. After major breakthroughs in healthcare, the average life expectancy in Oman has risen to 79.4 years in 2020 . Oman today has a total of 66 full-fledged public and private hospitals, equipped with state-of-the-art medical technology. While nine of the public hospitals are directly managed by the Ministry of Health, five are owned by Sultan Qaboos University, and the others are operated by the Armed Forces, the Royal Oman Police and other government institutions (WHO, 2019). Today, the total number of health centers, outpatient clinics, small local hospitals, and pharmacies across the country exceeds 226,000 in total (WHO, 2019). The World Health Organization (WHO), which has provided technical support to Oman since 1974, recognized Oman as one of the top 8 countries in the world in 2000 for the modernization of healthcare systems. Again, in 2016, the WHO awarded a certificate of appreciation to Oman's Ministry of Health for the successful health policies of the government. In less than two generations, infant and child mortality rates have decreased significantly due to improvements in healthcare. In Oman, the infant mortality rate has decreased to one-tenth of the official level in two decades, and again the mortality rate under five years of age has decreased fourteen-fold. Today, health services in Oman are provided almost free of charge to all citizens. (WHO, 2019).

5. Judiciary and Law: In the 1970s, Oman did not have a state with a structure that had institutions. It was such a structure in which the law was not adapted to the modern state system. The cases were conducted in accordance with the principles of Islamic law in matters involving personal, civil, and criminal offenses. Sultan Qaboos, who spent 20 years of his rule on the economic development of the country, began to make reforms in the field of law starting from the 1990s. The transformation of state institutions into today's modern state and the establishment of ministries, government, and the legal system took place in the 1990s. Over time, Sultan Qaboos gradually transformed the entire legal system into an institutionalized one and, with a comprehensive codification in 1996, the current state of the judicial system in the country emerged. Today Omani law is mainly in the form of a mixture of Sharia law and Anglo-Saxon law.

The Ministry of Justice was created for the first time in 1994. Appointments to all judicial positions are made by the Sultan. Today, the main legal institutions are made up of the Law Courts and the Supreme Judicial Council, which supervises their functioning. The legislature consists of the 'Primary' law, called the 'Royal Decree', and the 'Secondary' law enacted by ministries per the legislation. Sharia courts hear personal cases and those related to family law, while Administrative Courts deal with public/institutional cases. In addition, the powers of, military courts, and the military commissions established for emergency cases are determined by the Constitution.
The Constitutional Court also has the power to make a ruling on the compatibility of the courts' rulings with the Constitution when necessary. "Commercial Courts" were established in 1997, including 6 main central Commercial Courts and 45 Regional ones. In 1999, the Courts of Appeal began to function. In short, looking at the legal and judicial system of Oman, it is possible to find a highly developed and modern system and institutionalization in Oman.

6. Renaissance in the System of State and Government: From the moment Sultan Qaboos came to power in 1970, he aimed to establish a participatory system of governance, including all elements of Omani society, which had not been seen in the country until then. As early as the beginning of the 1970s, he formed the Council of Ministers, by appointing its members to equally reflect all regions of Oman, particularly its tribal, ethnic, and regional groups. This balanced political distribution was the first and most important political step for the new Sultan to be loved and respected throughout the country. A few years later, in 1981, he established the State Consultative Council [SCC] (AlMajlis Al-Istishari lil-Dawla), one of the most important steps of democratization in politics. Three years later, in 1984, the Council held its first session with its 45 members. The Sultan was no longer taking decisions without exchanging ideas with the State Consultative Council, which was made up of experts in their field in the country.

In 1990, as the twentieth anniversary of his coming to power was celebrated, Sultan Qaboos announced that he would replace the State Consultative Council with the Consultative Council (Majlis Al-Shura) endowed with broader competencies. From a historical point of view, the establishment of this institution was a turning point in Oman's modern political history and was the first step in a political plan designed to transition to a parliamentary system of government and an electoral system. This was because, while the State Consultative Council came to the administration by appointment, the Consultative Council, which was established then, would come to power by-elections. Following these decisions and parliamentary developments, Oman began to draw attention as the most democratic state among all Gulf States and to be cited as an example of "political evolution" for the countries of the region. The reaction from the public was quite positive because the people wanted to participate in politics and administration as well. The sheiks (tribal leaders), the governors (the state's authorized representative in the city), village elders, women, and men were ready to elect the lower house, which would govern them. The Sultan would often appear among the people, listen to their problems, and talk to them.

The Basic Statute of the State, the cornerstone of Oman's legal system, though its name is different, is essentially the country's first written constitution and was first introduced to the public in 1995 on the twenty-fifth anniversary of Sultan Qaboos' accession to the throne. 
This written constitution is a novelty that puts Oman ahead of other Gulf States. In fact, the political change and transformation in Oman brings the British revolution to mind rather than the French revolution. According to the newly adopted Constitution, the system of government of the Sultanate is permanent; his Majesty assumes a dual role as both the head of state and prime minister. The Sultan, who presides over a Council of Ministers that helps, advises, and enforces national policies, is also the Commander-in-chief of the Armed Forces and is tasked with enforcing national policies, promulgating laws, and appointing judges. The Sultan officially represents all three ministries: Ministry of Foreign Affairs, Ministry of Economy and Ministry of Defense.

Oman's Constitution offers more comprehensive human rights than any other Gulf country, including personal freedoms and civil rights. "It prohibits discrimination based on gender, origin, color, language, religion, sect, residence, or social status." It addresses the social duties governing the relationship between citizen and state and, more importantly, prioritizes the rule of law, including equality before the law, the principle of "presumption of innocence" and the right to legal representation. Although Islam is recognized as the state religion of Oman, it grants the believers of other religions the freedom to worship and perform their other religious duties. The main rule is based on respecting Omani traditions. In Oman, the foundation of the government is based on law, and, officially, the law/legal system can exercise its jurisdiction over everyone. With the last amendment to the Constitution made in 2011, today the Parliament of Oman is endowed with supervisory powers in the legislature and the executive. According to Article 58 of the Royal Decree (99/2011), the Parliament of Oman (officially called the Council of Oman) consists of the Council of State (Majlis-i Dawla-upper house) and the Consultative Council (Majlis al-Shura-lower house).

The Council of State (Majlis-i Dawla-upper house), consisting of 83 members, who are at least 40 years old, is an advisory body with financial and administrative independence. It contributes to the review of issues coming to parliament prepares work for the implementation of national development plans and helps to find appropriate solutions to issues raised in Parliament. Its members are appointed by the Sultan for 4 years. In these appointments, it is seen that the Sultan appoints the experts in their field almost every time. In short, "the job is always given to qualified people" in the Council of State. For example, if an expert is needed in Islamic banking or a person is needed for the Council of State to improve the country's economy, it has become customary for the Sultan to appoint a highly regarded expert in the country, the best professor in the field. In order to be officially elected to the Council of State, it is necessary to be in one of the following categories: former ministers, undersecretaries of a ministry or their counterparts, ex-ambassadors, ex-senior judges, retired senior officers, those who are known for their competence and experience in the field of science, art and culture, professors of universities, colleges, higher institutes, spiritual leaders, business people, and people who have done great service to the nation.

The main duties of the Council of State can be summarized as follows: (MOFA, 1995) preparing drafts and proposing them to Parliament, directing them to the government for review, sending them back to Parliament after the draft is reviewed by the lower house, approving or amending the draft laws referred to by the lower house and sending them to the Sultan for approval, discussing the country's annual budget with the recommendations of the lower house and sending it back to the Council of Ministers, if necessary.

The members of the Consultative Council (Majlis alShura), which is the lower house of the parliament and which consists of 86 members take office with general elections held every 4 years. The Consultative Council is formed by representatives from 61 provinces in 11 regions in Oman, who take office by-election. If a province has a population of less than 30,000 , a maximum of 1 representative can be elected to the Consultative Council and a maximum of 2 representatives can be elected if it has more population. Since there are no political parties in Oman, all candidates run as independent candidates. Thus, it is much easier to understand not only the political but also the socio-cultural tendencies of the people. For example, in the last election, a female candidate, who was not wearing the hijab, entered parliament for the first time, especially with the support of university women. In order to be a candidate for the Consultative Council, it is required to be at least 30 years old and have an associate degree from a 2-year college, and each candidate has the right to be re-elected without limitation.

The Consultative Council, the most important factor and institution that makes the Omani political system more democratic than any other Gulf country has been given extensive powers with the latest regulations in 2015. The most important of these are: to discuss and amend the draft laws prepared by the Council of Ministers and to present them to the Council of State, to discuss and advise on development plans and projects prepared by the Council of Ministers and on the annual budget of the state, and to present them to the Council of State, to express opinion on the government's draft laws and to evaluate the outcome of their findings, and to discuss the government's assessments and economic and social decisions. With the signature of at least 15 members of the Consultative Assembly, an investigation can be opened about any minister or a notice of parliamentary question may be given about his/her actions. It has the authority to report the results of the investigation directly to the Sultan. This authorization stands out as a rare one in the Gulf and even in many democratic government systems with parliamentary immunity. Ministers are obliged to submit an annual report to the Consultative Council during the implementation phase of the projects. The Consultative Council also has the right to call ministers and ask for clarification on this report. 
The Council of Ministers is appointed by the Sultan from among those elected, and the Sultan sometimes presides over the sessions of the Council of Ministers, and when he is not present at the session, the Prime Minister is the president of the Council of Ministers. Decisions are taken by secret ballot and an absolute majority of votes. As mentioned earlier, the powers of the Parliament of Oman have been extended gradually by the Sultan since 1996. With the latest powers granted in 2011, the Omani Parliament has become the largest and most democratic Parliament in the Gulf, along with Kuwait. The elected Consultative Council has the right to bring every issue to the parliament and vote for a draft law. If the draft law passed by the Consultative Council is passed by the Council of State, which is the upper house, by most votes, it becomes a law with the approval of the Sultan. This mandate and legislative power in the Parliament make Oman stand out as the most democratic parliamentary and political system among the other states in the Arabian Peninsula.

With the Electoral Law enacted in 2003, all men and women over the age of 21 have been given the right to participate in all political processes of the state, including elections. In fact, women in Oman have not been given the right to vote and to be elected because of a feminist demand, as in Europe. As with many reforms in Oman, it is a reformist decision formed because of the consultations of Sultan Qaboos with the Consultative Council. In fact, considering what Sultan Qaboos has done over the last 30 years, it is worth noting that the Sultan has set an example to other Gulf countries in terms of defending women's rights and prioritizing their role in national development. Immediately after the "education for all" campaign that started in the 1990s,

Sultan Qaboos began appointing women to important government positions, then to embassies, the Council of State and finally to the Council of Ministers. In fact, the Permanent Representative of Oman to the United Nations, which had been one of the top embassy positions for many years, and the Director of the Diplomacy Institute, the top vocational training school in the Ministry of Foreign Affairs were women with Ph.D. decrees. It should be noted that the university graduation rate in Oman is as high as $85 \%$, and 96 of the top 100 students graduated are female. While emphasizing the role of women in the development of the country is not easy in traditionalist structures, this has been achieved in recent decades in Oman, especially under the leadership of the Sultan. It is also a fact that in Oman, where $46 \%$ of the population is under the age of 19 , the trends followed by youth is an issue that must be addressed both politically and socio-culturally.

\section{CONCLUSION}

Considering the last fifty years, Oman went through a important transformation, the whole country has been established starting nearly from zero and has been able to access modernity convenient to the requirements of the 21st century. Even though petro-dollars seem to be, the most important reason explaining how the country reached out during this stage, in fact, the successful and reformist government of Sultan Qaboos was behind these reforms. After Sultan Qaboos came to power, the country entered a serious transformation process and reached its present developed status. In addition to this developed status, reforms made on political, cultural, and social rights also transformed the country seriously. The present Oman renaissance did not occur in a revolutionary manner as in France but evolutionarily like in Britain or the last periods of the Ottoman Empire. The most important role in this development has been played by the quality statesmen, the proceeds of multinational companies, and, of course, and the personal skills of Sultan Qaboos. Compared to other Gulf countries, the Omani government avoids waste and focuses only on the growth and infrastructural development of the country.

Holding the smallest economy in the Gulf after Bahrain, Oman settled the 2011 events by providing 50.000 new jobs to the public. Hence, it has been understood that the problem in Oman was not political but economic and today this problem has been resolved largely. Nowadays, Oman is placed at the 28th rank on the global level concerning its gross domestic product per capita amounting to 48,500 dollars and its nation lives in wealth and can allocate more time to individual activities outside working hours compared to developed Western societies. The fact that a country, that used to go into caves to cool off 50 years ago, reached this level of welfare today is considered a big success in every aspect and the Sultan Qaboos, who is the architect of this success, is commemorated with respect.

The new Sultan Haitham bin Tariq Al-Said came to power as a name that has been in politics for years and was behind the scenes in the Oman-2040 Vision, one of the most important projects of the country. With this aspect, Sultan Haitham can be evaluated as the name that knows the best for the country and that would shape the future vision most successfully. The most important challenge that Oman would face in the next decade is to be able to diversify its economy to prevent that it is influenced by sudden fluctuations in oil prices. Despite five-year plans, unfortunately, Oman has not been able to diversify its economy as required partly due to the climate, partly due to the carelessness of multinational companies, partly due to the red tape, and partly due to the multiple conditions required in the subsidies given to local companies. This would be the most important focal point of the new government in the coming term.

Author Contributions: Conceptualization, MCY.; methodology, MCY, SB.; software, SB.; validation, MCY, SB; formal analysis, MCY.; investigation, MCY; resources, MCY; data curation, MCY, SB; writing-original draft preparation, MCY, SB; writing-review and editing, MCY, SB; visualization, MCY; supervision, MCY, SB; project administration, MCY; funding acquisition, MCY, SB. All authors have read and agreed to the published version of the manuscript. 
Funding: This research received Internal Grant from SQU- CEPS No: IG/EPS/POLS/20/01

Conflicts of Interest: The authors declare no conflict of interest.

\section{REFERENCES}

CIA Factbook (2020) Oman. CIA Press, NY.

DIAM, Public Authority for Water, https://www.diam. om/Our-role-in-Oman/Supply-drinking-water-in-Oman (accessed 27 May 2020)

Expat Insider 2019, "The Best \&t Worst Places for Expats in 2019”. https://www.internations.org/expatinsider/2019/best-and-worst-places-for-expats-39829 (Accessed 16 June 2020).

Gulf World "Oman's foreign minister says there is no Gulf union” 06. 06. 2012.

Gupta, S. (2016) Oman: The Unsung Hero of the Iranian Nuclear Deal. International Policy Digest Vol 18 No 2 pp. 12-19.

Hellenic Shipping News Worldwide "Oman's Crude Production Crosses 29 mn Barrels level” 15.10.2019.

MOFA-Ministry of Foreign Affairs (2020) "Council of Oman”, https://www.mofa.gov.om/?p=792\&lang=en (Accessed 4 September 2020).

Nasser, R. (2019) Educational Reform in Oman: System and Structural Changes Intech Open Journal Vol 6 No 2) pp. 116-132

NRAA-National Records and Archives Authority (2016) Omani and Ottoman Political Military and Economic Relationships. NRAA Press Muscat.

Oman Ministry of Education (2020) Oman Education Council Report. MOE Press Muscat.

Oman Ministry of Foreign Affairs (1995) Sultan's Speeches. MOFA Publishing Muscat.

Oman Ministry of Higher Education (2020) Oman
Education Council Report. MOE Press Muscat. Oman Water Society (2020) http://www.omanws.org. om/en/page/dams (accessed 26 May 2020)

ONCSI-Oman National Center for Statistics and Information (2020) Manafeth- Oman Trade Statistical Gateway. "United Kingdom, China, South Korea, India, Japan” https://manafeth.ncsi.gov.om/ (Accessed June 26, 2020)

QS World University Ranking (2020) https://www. topuniversities.com/node/3537/ranking-details/worlduniversity-rankings/2020 (Accessed 3 June 2020)

Sohar Port and Free Zone (2020) http://www. soharportandfreezone.com/ (accessed, 30 May 2020)

Tuzlukova, V, Inguva, M. Sancheti, P. (2019) Oman General Foundation Programs Focus on General Education. Theory and Practice in Language Studies Vol 9, No 4 pp. 480-486.

UN World Populations Prospects (2019) https:// population.un.org/wpp/ (accessed 4 June 2020)

US Embassy to Oman (2020) Historical Background of US- Oman Relations https://om.usembassy.gov/ our-relationship/us-oman-relationship/ (Accessed 10 September 2020)

US Energy Data Center (2020) World Energy Production. US Press Washington.

World Bank Data Center (2020) https://data.worldbank. org/country/oman (Accessed 13 September 2020)

World Health Organization (2019) EMRO: Health System Profile-Oman; WHO-UN Press: New York.

Yenigun C., (2015) In NATO's Approach to Gulf Cooperation (edited by Firuz Demir). Gulf Security, NATO and Istanbul Cooperation Initiation. pp. 33-54 ECSSR Publications, Abu Dhabi.

Yenigun, C. Basoos H. Hassan, G. (2020) Negotiation Level between EU and the GCC. International Journal of Innovation, Creativity and Change Vol 14 No 11, 65-75. 